\title{
The Effectiveness of Phytochemical Components and Climatic Factors on Population Fluctuation of the Spider Mite, Tetranychus urticae Koch on Sweet Pea and Pea Crops
}

\author{
Marwa S. Kamel ${ }^{*}$, Aziza M. Abou-Zaid ${ }^{2}$ and Samia A. Yasin ${ }^{2}$ \\ ${ }^{1}$ Plant Protection Department, Faculty of Agriculture, Suez Canal University 41522, Ismailia, Egypt \\ ${ }^{2}$ Plant Protection Research Institute, (ARC). Dokki, Giza.Egypt.
}

Received: 5/10/2019

\begin{abstract}
Studies were conducted to define the level infestations of sweet pea and pea crops to the infestation of the spider mite, Tetranychus urticae Koch, and its predatory mite Amblyseius swirskii (Athias-Henriot) during two successive seasons (2016-2017 and 2016-2017) at El- Ayyat - Giza Governorate. Results appeared that the infestation of two cultivars by T. urticae was begun in the first week of October under greenhouse conditions. Progressively increased till its peaks in the third week of June for (sweet pea) and in the first week of February for (pea) during the two successive seasons. Through two consecutive seasons, sweet pea cultivar was the most highly sensitive than pea, arranged in a descending order as follows: sweet pea (75.58, 74.37 and 74.19\%), (76.30, 75.87 and $74.95 \%)$ and pea (24.41, 25.62 and 25.80\%), (23.96, 23.51 and 25.04\%). Subsequently, sweet pea cultivar highly susceptible (36.62 \pm 3.236$),(47.75 \pm 4.395)$ and $(45.73 \pm 4.193)$ adult, immature and egg, respectively in season 2017-2018 and the lowest infested are pea cultivar (10.71 \pm 1.249$)(13.66 \pm 1.632)$ and (14.61 \pm 1.729$)$ adult, immature and egg, respectively in season 2016-2017. Cultivars (sweet pea and pea) contain remarkable rates of the predatory mite, A. swirskii through two successive seasons. Phytochemical contents were evaluated in uninfested and infested leaves at peak infestation and the final season of 2017. In addition, there is a positive relationship between mite infestation levels and total carbohydrates and nitrogen in sweet pea and pea leaves, however a negative relationship found with total phenolic compounds. Infested leaves of sweet pea and pea cultivars contained a low concentration of phosphate and potassium $(1.065,2.165) \&(0.54,1.17)$ at the late season.
\end{abstract}

Keywords: Climatic factors, phytochemical leaf, Sweet pea and Tetranychus urticae

\section{INTRODUCTION}

Pea Pisum sativum is a vital crop. It has many nutritional values such as high content of protein, carbohydrates, phosphorus, iron, calcium and vitamins A and B (Hassan, 1997). In addition, it is a rich source of a prevalence of minerals and vitamin $\mathrm{C}$ (Bhat et al., 2013). Thus, pea is used as a fresh and frozen.

Moreover, the total cultivated area for pea in Egypt was 42524 fed. and produced total yields about 181.000 tons with average 4.24 ton/fed. (Dep., Agric., Statistics, Ministry of Agriculture, Giza, Egypt, 2013).

Recently, the successful cultivation for pea (Lincoln cultivar) and sweet pea (snap pea cultivar) are threatened by several pests. For instance, there are a two spotted spider mites (TSSM) Tetranychus urticae Koch, blue oat mite (Penthaleus major) and red-legged earth mite (Halotydeus destructor). Further, Tetranychus urticae is a polyphagous herbivore which feeding on more than 1,100 plant species (Grbic et al., 2011). Tetranychus urticae Koch was a serious polyphagous, cosmopolitan pest on majority of economic yields, which is easily spread on the wind. Under optimum conditions (Cvidanes et al., 1990).

Consequently, (TSSM) is considered the most important pest that causes an economic damage to vegetables crops in Egypt. Furthermore, it is considered a serious problem to plants worldwide, attacking crops. When mites' injury crops of economic importance the impacts can be felt globally. Mites are amongst the most diverse and succeeded, of invertebrates. TSSM has a very rapid population growth, short developmental time, high birth rate and long adult survival (Clotuche, 2011).
In the recent years, the environmental priority of varied vegetable crop pests has obtained a significant importance in pest control. However, some studies were achieved with regard to the effect of climatic factors in the population dynamics of damage as well as controlling pests infesting vegetable crops which studied by many authors, (El-Kawass, 2000; AbouZaid, 2003). On the other hand, the red spider mite spread to all parts of the plant as the population increases especially during dry period and produce webbing over the entire plants. However, Moderate population may greatly affect on crop production and heavy infestation results in death of the plant. Therefore, Chemical contents which normally vary from variety to another, may affect the population level of mites (Abdallah et al., 2009).

Thus, the present research work is conducted to achieve some objectives. Firstly; evaluate the population fluctuations of $T$. urticae and associated its predatory mite, (Amblyseius swiriski Athias-Henriot) on each of pea and sweet pea crops during two years 2016-2017 and 2017-2018. Secondly; leaf chemical contents. Finally, correlation with certain weather factor on population of (TSSM) Tetranychus urticae Koch.

\section{MATERIALS AND METHODS}

\section{Experimental design and Counting}

This investigation was carried out in El- Ayyat Giza Governorate, Egypt. Pea and sweet pea (Pisum sativum) (Lincoln cultivar) and sweet peas (Pisum sativum var. macrocarpon) (snap pea cultivar) crops were cultivated in greenhouse during the two seasons 
2016-2017 and 2017-2018. The greenhouse $(50 \times 70$ $\mathrm{m}^{2}$ ) was divided into 6 equal plots. Each plot was replicated. Each replicate was $500 \mathrm{~m}^{2}$. The plots were arranged in a randomized complete block design (RBCD) for each cultivar. Experiential plots were given the standard cultivation practices including organic and mineral fertilization, drip irrigation and mechanical control was applied to remove weeds. Pesticides were avoided completely. The first season began from $25^{\text {th }}$ September 2016 up to $15^{\text {th }}$ March 2017; while second season began from $27^{\text {th }}$ September 2017 up to $21^{\text {st }}$ March 2018. Each Sample of 30 leaves was weekly collected from every peas cultivar and examined for Adult, immature stages and the eggs of $T$. urticae occasion. The collected samples of the two spotted spider mite were identified and sorted to the stage and counted bi- weekly for each stage on each plant using stereoscopic binocular microscope (Zaher, 1984). While, the predatory mites were counted in the whole leaf area as reported by Poe (1980).

\section{Definition of phytochemical leaf components of the two cultivars}

Chemical analysis was carried out in the growing season of the two pea cultivars during the vegetation growth period. The sweet pea and Pea leaves were collected and prepared for chemical analysis at laboratory of the Faculty of Agriculture Research Park, Cairo Univ. for chemical analysis. (Nitrogen was determined and calculated according method described by Sadasivam and Manickam (1991). Furthermore, Potassium and total phenols contents were conducted by method of Chapman and Pratt (1961). Finally, total of carbohydrates and proteins were estimated and conducted according to method of Bradford (1976).

\section{Statistical analysis:}

The statistical analysis (ANOVA, Simple correlation and partial regression) of the obtained data were performed by using SAS program (SAS Institute, 1988). Also, the difference between means was conducted by using Duncan's multiple range tests in this program. The reduction percentages in the number of pests were calculated by using equation of Henderson and Tilton (1955).

\section{RESULTS AND DISCUSSION}

Population fluctuation of the two spotted spider mites, Tetranychus urticae and predatory mite, Amblyseius swirskii (Athias-Henriot) on leaves of sweet pea and pea cultivars for two seasons 2016-2017 and 2017-2018 are shown in Tables (1, 2 and 3) and Figure (1). Data illustrated that initial growth of population increases as the plant grows. Thus, the susceptibility of two Pea cultivars to the adult, immature and egg stages of T. urticae started in the first week of October, gradually increased and reached its peaks in the $3^{\text {rd }}$ week of June. The elevated numbers of adults, immature and eggs of spider mite averaged (52.71, 70.14 and 68.11), (58.66, 80.11 and 76.11) individuals/leaf on sweet pea cultivar during two successive seasons, respectively, While, in the pea cultivar the infestation started in the Last week of October, but increased gradually till reached its peaks in the first week of February. The mean values were recorded for the same stages $(18.98,25.11$ and 26.11), (19.24, 27.1 and 27.13) individuals/leaf, respectively. Thus, the population has dropped in the fourth week of March. Finally, the mean numbers of $T$. urticae and infestation adult, immature, eggs percentages (Tables 1, 2 and 3) during the two successive seasons. It could be arranged in a descending order as follows: sweet pea $(75.58,74.37$ and $74.19 \%),(76.30,75.87$ and $74.95 \%)$ and pea $(24.41,25.62$ and $25.80 \%)$, (23.96, 23.51 and $25.04 \%$ ). Subsequently, sweet pea cultivar was highly susceptible whereas, it harbored $(36.62 \pm 3.236),(47.75 \pm 4.395)$ and $(45.73 \pm 4.193)$ adult, immature and eggs, respectively in the season 2017 2018 and the lowest infested are pea cultivar (10.71 \pm 1.249$),(13.66 \pm 1.632)$ and $(14.61 \pm 1.729)$ adult, immature and eggs, respectively in season 2016-2017. Statistical analysis show that the average numbers of the T. urticae was significantly high on the sweet pea leaves comparing with pea leaves. There is a significant variation in the population of $T$. urticae between the two seasons, where, population increased gradually with plant age during the two seasons, then decreased gradually to reach the lowest rate at the end of inspections. Moreover, this result clearly indicated that young fresh plants are more suitable for T. urticae.

Table (1): Evaluation of two peas crops for their relative susceptibility to immatures of T. urticae during (2016-2018) seasons

\begin{tabular}{|c|c|c|c|c|}
\hline \multirow{3}{*}{ Cultivars } & \multicolumn{4}{|c|}{ Mean number of $T$. urticae Adult/leaf } \\
\hline & \multicolumn{2}{|c|}{ 2016-2017 } & \multicolumn{2}{|c|}{ 2017-2018 } \\
\hline & Mean \pm S.E & Infestation \% & Mean \pm S.E & Infestation \% \\
\hline Sweetpeas.A & $33.15^{\mathrm{a}} \pm 2.923$ & $75.58 \%$ & $36.62^{\mathrm{a}} \pm 3.236$ & $76.30 \%$ \\
\hline peas.A & $10.71^{\mathrm{b}} \pm 1.249$ & $24.41 \%$ & $11.54^{\mathrm{b}} \pm 1.352$ & $23.96 \%$ \\
\hline
\end{tabular}

\section{LSD value at 0.05}

6.392

6.834

- Means with same letter are not significantly different 
Table (2): Evaluation of two peas crops for their relative susceptibility to adult stages of T. urticae during (2016-2018) seasons

\begin{tabular}{lcccc}
\hline \multirow{2}{*}{ Cultivars } & \multicolumn{4}{c}{ Mean number of T. urticae Immature /leaf } \\
\cline { 2 - 5 } & \multicolumn{2}{c}{$\mathbf{2 0 1 6 - 2 0 1 7}$} & \multicolumn{2}{c}{$\mathbf{2 0 1 7 - 2 0 1 8}$} \\
\cline { 2 - 5 } Sweet peas. A & $39.65^{\mathrm{a}} \pm 3.745$ & $74.37 \%$ & $47.75^{\mathrm{a}} \pm 4.395$ & Infestation\% \\
\hline peas. A & $13.66^{\mathrm{b}} \pm 1.632$ & $25.62 \%$ & $14.68^{\mathrm{b}} \pm 1.709$ & $75.87 \%$ \\
\hline
\end{tabular}

$\begin{array}{lll}\text { LSD value at } \mathbf{0 . 0 5} & 8.214 & 9.153\end{array}$

- Means with same letter are not significantly different

Table (3): Evaluation of two peas crops for their relative susceptibility to eggs of T. urticae during (2016-2018) season

\begin{tabular}{|c|c|c|c|c|}
\hline \multirow{3}{*}{ Cultivars } & \multicolumn{4}{|c|}{ Mean number of $T$. urticae Immature /leaf } \\
\hline & \multicolumn{2}{|c|}{ 2016-2017 } & \multicolumn{2}{|c|}{$2017-2018$} \\
\hline & Mean \pm S.E & Infestation $\%$ & Mean \pm S.E & Infestation \% \\
\hline Sweet peas. A & $42.01^{\mathrm{a}} \pm 3.877$ & $74.19 \%$ & $45.73^{\mathrm{a}} \pm 4.193$ & $74.95 \%$ \\
\hline peas. A & $14.61^{\mathrm{b}} \pm 1.729$ & $25.80 \%$ & $15.28^{\mathrm{b}} \pm 1.800$ & $25.04 \%$ \\
\hline LSD value at 0.05 & \multicolumn{2}{|c|}{8.535} & \multicolumn{2}{|c|}{8.851} \\
\hline
\end{tabular}

- Means with same letter are not significantly different

Thus, the outcome of this study point out that the population of $T$. urticae was a considerable increase between November and April month. This result agree with Fisher and Mourrut (2005) and Fawzy et al. (2004), where found that concerning the mite, population of $T$. urticae descend abruptly on peppermint after arriving a peak during April and the population dynamics of $T$. ludeni on okra appeared in the first of November and their peak was recorded in April. Identical conclusion was attained by Croft et al. (2005). T. urticae population was affected by seasons, where most of the mites remain in the field all over the year with minimum level during winter season (Sharma and Pati, 2012; Kanika and Geroh, 2016). Tripathi et al. (2013) who found that with high population of T. urticae in June and July and lower to negligible mite population was encountered through December, January and February months.

Correlation Coefficient " $r$ " between $T$. urtica population and both of Temperature and Relative humidity:

The effect of climatic factors on the appearance of T. urticae on cultivars was also addressed. Tables
(4 and 5) are shown the correlation coefficient " $\mathrm{r}$ " revealed that significant positive correlations between phytophagous mite, T. urticae (adult, immature, egg) population and both of maximum temperature $(\mathrm{r}=0.895,0.866$ and 0.895$)(\mathrm{r}=0.776,0.798$ and 0.802$)$ on sweet pea respectively in seasons 2016-2017 and 2017-2018. On the other hand, Data of pea cultivar was $(\mathrm{r}=0.928,0.921$ and 0.928$)(\mathrm{r}=0.715,0.634$ and 0.625$)$, respectively in the same seasons. Whereas, minimum temperature was insignificant positive influence on the population. While, relative humidity (R.H) appears strongly significantly negative correlation.

The relation was looked between the daily mean relative humidity and T. urtica population, $(\mathrm{r}=-0.489$, 0.486 and -0.495$),(\mathrm{r}=-0.291,-0.286$ and -0.284$)$ and $(\mathrm{r}=-0.346,-0.357$ and -0.347$),(\mathrm{r}=-0.192,-0.141$ and 0.126 ) on sweet pea and pea during $1^{\text {st }}$ and $2^{\text {nd }}$ seasons, respectively.

The fractional regression analysis for the influence of maximum and minimum temperature on the population shows significant positive influence on two seasons; whereas, relative humidity have a significant positive effect.

Table (4): Interaction between climatic factors of two pea cultivars leaves and T. urticae population (2016-2017)

\begin{tabular}{|c|c|c|c|c|c|c|c|c|c|}
\hline \multirow{5}{*}{ Cultivars } & \multicolumn{9}{|c|}{ Correlation coefficient values } \\
\hline & \multicolumn{9}{|c|}{ 2016-2017 } \\
\hline & \multicolumn{6}{|c|}{ Temperature } & \multicolumn{3}{|c|}{ Relative humidity } \\
\hline & Max & Min & Max & Min & $\operatorname{Max}$ & Min & \multirow{2}{*}{ Ault } & \multirow{2}{*}{ immature } & \multirow{2}{*}{ Egg } \\
\hline & \multicolumn{2}{|c|}{ Adult } & \multicolumn{2}{|c|}{ Immature } & \multicolumn{2}{|c|}{ Egg } & & & \\
\hline Sweet pea & 0.895 & 0.845 & 0.866 & 0.822 & 0.895 & 0.867 & -0.495 & -0.486 & -0.489 \\
\hline pea & 0.928 & 0.947 & 0.921 & 0.941 & 0.928 & 0.944 & -0.346 & -0.347 & -0.357 \\
\hline
\end{tabular}


Table (5): Interaction between climatic factors of two pea cultivars leaves and T. urticae population (2017-2018)

Correlation coefficient values

\begin{tabular}{|c|c|c|c|c|c|c|c|c|c|}
\hline \multirow{4}{*}{ Cultivars } & \multicolumn{9}{|c|}{ 2016-2017 } \\
\hline & \multicolumn{6}{|c|}{ Temperature } & \multicolumn{3}{|c|}{ Relative humidity } \\
\hline & $\operatorname{Max}$ & Min & $\operatorname{Max}$ & Min & Max & Min & \multirow{2}{*}{ Ault } & \multirow{2}{*}{ immature } & \multirow{2}{*}{ Egg } \\
\hline & \multicolumn{2}{|c|}{ Adult } & \multicolumn{2}{|c|}{ Immature } & \multicolumn{2}{|c|}{ Egg } & & & \\
\hline Sweet pea & 0.776 & 0.891 & 0.798 & 0.901 & 0.802 & 0.897 & -0.291 & -0.286 & -0.489 \\
\hline pea & 0.715 & 0.928 & 0.634 & 0.91 & 0.625 & 0.924 & -0.192 & -0.141 & -0.357 \\
\hline
\end{tabular}

Temperature was the most extensively studied of all-climatic factors and it appears to have large effects (Haque et al., 2011). Hanafy et al. (2014) who found that temperature had a positive effect on mite population on many vegetable crops such as lady's finger, cucumber, tomato, eggplant, bottle gourd and bean. Comparable correlations between temperature and population density of $T$. arabicus on eggplant (Pratt el al., 2003). The population of Tetranychus ludeni on eggplants raise was related with periods of lower relative humidity and higher mean temperatures.

\section{Predacious mites Amblyseius swirskii (Athias-Henriot)}

A. swirskii was a useful predatory mite epidemic to the Eastern Mediterranean region. A. swirskii has attracted as a biological control agent of mites, thrips and whiteflies in greenhouse.

Several studies have announced that phytoseiids have a role to play in the control of acarine pests (Sano Soo and Palk, 1999; Rasmy et al., 2003). Therefore, the population fluctuation of $A$. swirskii predators was studied during the two successive seasons 2016-2017, 2017-2018.

Furthermore, the common trends in the appearance and the abundance of the predator mite $A$. swirskii is given in Fig (1). It was predominant in Sweet pea and was found in $(76.22 \%)$, (73.96) of leaf samples pea cultivar came second in the abundance forming $23.77 \%, 26.03$ of the total samples, respectively. Therefore, predators were also see in higher numbers on plants infested with whiteflies than on uninfected ones especially $A$. swirskii (Nomikou et al., 2002).

The population intensity began to increase in November, and then oscillated till reached a peak in Marsh. These facts mention that prey probably play an important role of the predator diet. The information is in accordance to Abou-Awad et al. (2017).

However, it is difficult to explain the accurate reasons for variation of predacious mites and their numbers because of the intricacy involved in the multiple predator - prey relationships. Phytoseiid mites like A. hibisci (Chant) (McMurtry et al., 1970) and $A$. swirskii Athias-Henriot (Abou-Awad et al., 2000) were reported to use eriophyids as a food source, but they do not reduce them, due to they do well on tetranychid species, such as T. urticae Koch (Mc-Murtry and Scriven, 1964).

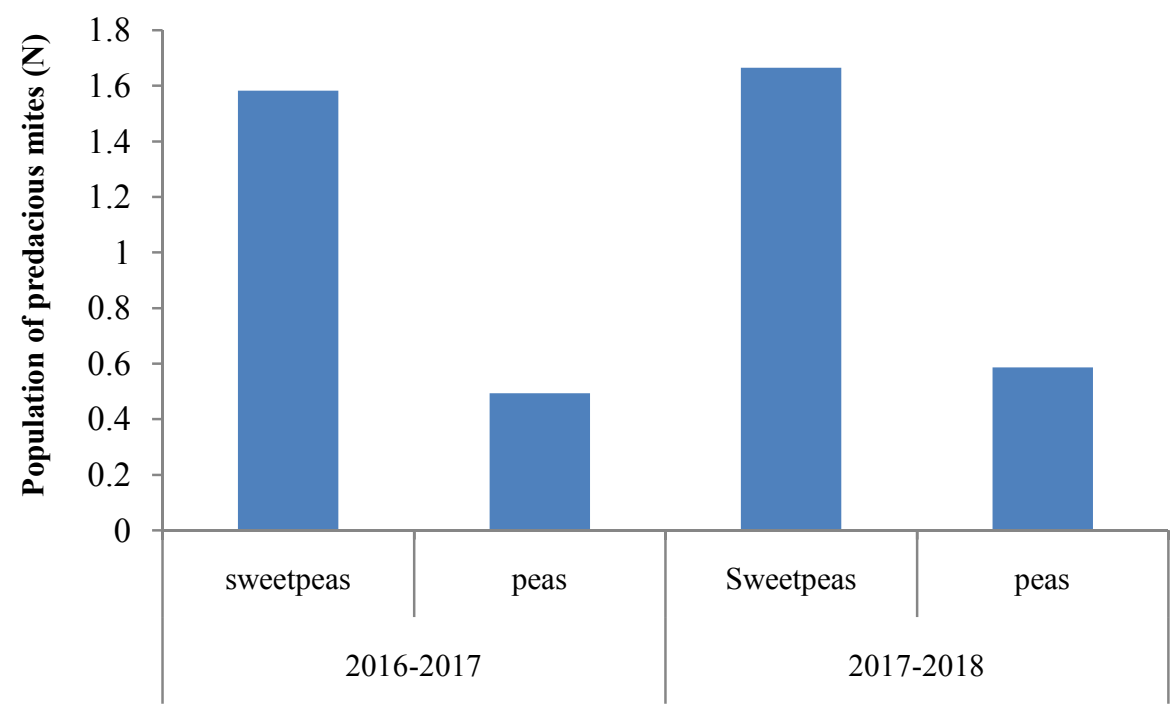

Fig. (1): Population density of the predatory mite, A. swirskii on two cultivars sweet peas and peas during two seasons, (2016-2017 and 2017-2018) 
Phytochemical components and population of spider mites, Tetranychus urticae

The Data of phytochemical analysis at the time of infestation peak and the end of season during 2017, determine that there were higher changes happened in the phytochemical contents of the invaded leaves of the two pea cultivars. As we are familiar with, leaf chemical contents are knew one of most important factors which play a role in the susceptibility of sweet pea and pea cultivars to T. urticae infestation.

Data indicated that there was a positive relationship between mite infestation levels and total carbohydrates in sweet pea and pea leaves, while a negative relationship found with total phenolic compounds (Table 6). Infested leaves of sweet pea and pea cultivars contained decreased concentrations of phosphate and potassium $(1.065,2.165)$ and $(0.54$, $1.17)$ at the late season.

Regarding sweet pea cultivar, it was observed that the higher contents of all leaf contents than other cultivar except on total phenols of 1.29. Also, it had the highest average mean of the T. urticae (121.25 mites/leaf) and the lowest content were recorded in pea cultivar (Table 4). On the other hand, there were increased concentrations in nitrogen (4.65, 3.245) contents in sweet pea and pea cultivars. These results are coincided with Maklad (2004), Abdallah et al. (2009), Aiad et al. (2014) and Fatma et al. (2015).

Table (6): Relationship between phytochemical components of two peas cultivars leaves and population of Tetranychus urticae.

\section{Phytochemical contents}

\begin{tabular}{|c|c|c|c|c|c|c|c|c|}
\hline Cultivars & 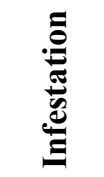 & $\begin{array}{c}\text { Mean of } T . \\
\text { urticae } \\
\text { movable } \\
\text { stage }\end{array}$ & $\mathbf{N}$ & $\mathbf{P}$ & $\mathbf{K}$ & $\begin{array}{l}\text { Total } \\
\text { phenolic } \\
\text { compounds } \\
\text { g/100g }\end{array}$ & $\begin{array}{c}\text { Total } \\
\text { Protein } \\
\text { compounds } \\
\text { g/100g }\end{array}$ & $\begin{array}{c}\text { Total } \\
\text { Carbohydrates } \\
\text { compounds } \\
\text { g/100g }\end{array}$ \\
\hline \multirow{3}{*}{$\begin{array}{c}\text { Sweet } \\
\text { peas }\end{array}$} & low & 3.2 & 4.32 & 1.02 & 1.99 & 1.35 & 24.44 & 57.98 \\
\hline & High & 239.3 & 4.98 & 1.11 & 2.34 & 1.23 & 27.43 & 57.75 \\
\hline & Mean & 121.25 & 4.65 & 1.065 & 2.165 & 1.29 & 25.935 & 57.865 \\
\hline \multirow{4}{*}{$\begin{array}{c}\text { Regu. } \\
\text { peas }\end{array}$} & Low & 0.01 & 2.73 & 0.49 & 1.23 & 2.02 & 13.23 & 42.37 \\
\hline & High & 20.14 & 3.76 & 0.59 & 1.11 & 1.68 & 16.21 & 54.13 \\
\hline & Mean & 10.075 & 3.245 & 0.54 & 1.17 & 1.85 & 14.72 & 48.25 \\
\hline & low & 3.2 & 4.32 & 1.02 & 1.99 & 1.35 & 24.44 & 57.98 \\
\hline
\end{tabular}

\section{REFERENCES}

Abdallah, A. A., E. M. A. El-Saiedy, M. E. Sholla, Salwa and M. M. El-Fatih (2009). Field and Laboratory studies to evaluate three Squash cultivars for their relative susceptibility to spider mite Tetranychus urticae Koch and three sucking insect species. Minufiya, J. Agric. Res., 34(5):1913-1926.h

Abou-Awad, B. A., B. M. El-Sawaf, A. S. Reda, A. A. Abdel-Khalek (2000). Enviromental management and biological aspects of two eriophyoid fig mites in Egypt: Aceria ficus and Rhyncaphytoptus ficifoliae - Acarologia, 40: 419-429.

Abou-Awad, B. A., S. I. Afia and E. M. A. El-Saiedy (2017). Population dynamics of Tetranychidmite and its predator on watermelon and musk melon and effect of mite feeding on the phytochemical components of the host plants. Bioscience Research, 14(4): 879-886.

Abou-Zaid, A. M. M. (2003). Studies on some mites associated with some vegetable crops. M. Sc. Thesis, Fac. Sci. Al-Azhar Univ., 150 pp.

Aiad, A. K., E. M. A. El-Saiedy and A. H. M. Romeih (2014). Susceptibility of three muskmelon Cucumis melo L. cultivars to infestation with
Tetranychus urticae Koch. J. Acarines, 8: 5961.

Bhat, T. A, M. Gupta, M. A. Ganai, R. A. Ahanger and H. A. Bhat (2013). Yield, soil health and nutrient utilization of field pea (Pisum sativum L.) as affected by phosphorus and Biofertilizers under subtropical conditions of Jammu, International journal of modern plant and animal science, 1(1):1-8.

Bradford, M. M. (1976), "Rapid and sensitive method for the quantization of microgram quantities of protein utilizing the principle of protein-dye binding", Anal. Biochem., 72(1-2): 248-254.

Chapman, H. D. and F. P. Pratt (1961). Ammonium vandate-molybdate method for determination of phosphorus. Methods of analysis for soil, plants and water $1^{\text {st }}$ Edn., California university. Agriculture. Division, USA, pp: 184-203.

Clotuche, G. (2011). The silk as a thread to understand social behaviour in the weaving mite Tetranychus urticae. $\mathrm{PhD}$ dissertation, Universite catholique de Louvian, Belgium.

Croft, P., R. Jacobson and J. Fenlon (2005): Impact of biological and behavioural variation in spider mites (Acari: Tetranychidae) on the success of 
IPM of UK tomato crops. Bulletin OILB/SROP, 28(1): 71-74.

Cvidanes, F., M. J. Tromozine and L. H. Siluestre (1990). Distribution of Tetranychus urticae (Koch). (Acari-Tetranchidae). Cientifica, 15(2) 147-155.

El-Kawas, H. M. G. (2000). Ecological and biological studies on some mites associated with orchards and field crops. M.Sc. Thesis, Fac. of Agric., Al-Azhar Univ., 154 pp.

El-Saiedy, E. M. A., A. M. Afifi, S. A. Fatma and M. M. Ahmed (2011). Susceptibility of four watermelon cultivars to infestation with Tetranychus urticae Koch. Acarines, 5: 23-28.

Fatma, S. A., A. M. Afifi, E. M. A. El-Saiedy and M. M. Ahmed (2015). Effect of phytochemical components, morphological and histological leaf structure on five tomato hybirds on Tetranychus urticae Koch infestation. Acarines, 9: 23-30.

Fawzy, M. M. H., N. M. A. El-Wahed and K. M. ElSayied (2004). Biological control of the twospotted spider mite (Acari: Tetranychidae) with Phytoseiulus persimilis (Acari: Phytoseiidae) on commercial cucumber in Sharkia Governorate. Annals of Agricultural Science, Moshtohor, 42 (1): 357- 364 .

Fischer, S. and S. J. Mourrut (2005). Tomato Russet Mite in Switzerland (Aculops lycopersici: Acari, Eriophyidae). Revue Suisse de Viticulture, Arboriculture et Horticulture, 37(4): 227- 232.

Grbic, M, T. Van Leeuwen, R. M. Clark, S. Rombauts, P. Rouze, V. Grbic, E. J. Osborne, W. Dermauw, P. C., Ngoc F. Ortego et al. (2011). The genome of Tetranychus urticae reveals herbivorous pest adaptations. Nature, 479 (7374): 487-492

Hanafy, A. R., F. Baiomy and M. A. Tantawy (2014). Comparison between the infestation rate of certain pests on cucumber and kidney bean and its relation with abiotic factors and anatomical characters. Egypt. Acad. J. Biolog. Sci., 7(2): 63 -76 .

Haque, M. A., T. R. Islam, N. A. Naher and M. M. Haque (2011). Seasonal abundance of spider mite Tetranychus urticae Koch on vegetable and ornamental plants in Rajshahi. University. J. Zool. Rajshahi Univ., 30: 37-40.

Hassan (1997). Vegetable fruits. Al-Dar Al-Arabia Publications and distribution, Cairo, Egypt, pp: 241.

Henderson, C. F. and W. A. Tilton (1955). Test with acaricides against the wheat mite. J. Econ. Ent. 49: 157-161.

Kanika, R. G. and M. Geroh (2016). Host Plant Responses to Tetranychus urticae Koch Mediated Biotic Stress and Management
Strategies. C. Chattopadhyay and D. Prasad (eds), Dynamics of Crop Protection and Climate Change (C) Studera Press. 93-114 pp

Makled, A. M. (2004). Ecological studies on some insects and animal pests infesting certain vegetable crops under protected cultivation and their control. M. Sc. Thesis. Fac. of Agric. AlAzhar Univ., 321 pp.

McMurtry, J. A., G. T. Scriven (1964). Studies on the feeding, reproduction, and development of Amblyseius hibisci (Acarina: Phytoseiidae) on various food substances. Ann. Entomol. Soc. Am., 57: 649-655.

McMurtry, J. A., C. B. Huffaker, M. Van De Vrie (1970). Ecology of tetranychid mites and their natural enemies: A review 1. Tetranychid enemies: Their biological characters and the impact of spray practices. Hilgardia, 40: 331390.

Poe, S. L. (1980). Sampling mites on soybean. In: Kogan, M. and D. C. Hezrog (eds) Sampling methods in soybean entomology. SpringerVerlag, New York, pp. 312-323.

Pratt, P. D., E. M. Coomb and B. A. Croft (2003). Predation by phytoseiid mites on Tetranychus lintearius (Acari: Tetranychidae), an established weed biological control agent of gorse (Ulex europaeus), Biological control, 26(1): 40-47.

Rasmy, A. H., F. A. Momen, M. A. Zaher, G. M. Abou-Elela (2003). Influence of diet on life history and predatory capacity of Amblyseuis Zaheri Yousef and El-Brolossy (Acari: Phytoseiidae). Insect Sci. Applic., 23: 31-34.

Sadasivam, S. and A. Manickam (1991). Second edition, Biochemical methods. New age International Publishers

Sano Soo, K. I. M., C. H. Palk (1999). Perdition of five species of phytoseiid mites on Panonychus citri and Aculops pelekassi. Kor. J. Entomol., 29: 261-264.

SAS Institute (1988). SAS/Stat user's guide, 6.03 ed. SAS institute, Cary, NC

Sharma, A. and P. K. Pati (2012). First record of the carmine spider mite, Tetranychus urticae, infesting Withania somnifera in India. J. Insect Sci., 12: 1-4.

Tripathi .M. K., A. Kumar and D. K. Srivastava (2013). Seasonal incidence of mites, Tetranychus urticae Koch and T. ludeni Zacher on okra and brinjal crops. Ann. Pl. Protec Sci., 22: 52-55.

Zaher, M. A. (1984). Survey and ecological studies on phytophagous, predaceous and soil mites in Egypt. I: Phytophagous mites in Egypt (Nile valley and Delta). PI 480 Programme. USA Project No. EG. ARS, 30. Grant. No, FG, Eg., 81. 228 pp. 


\title{
فعالية المركبات الكيميائية والعوامل المناخية على تعداد أكاروس العنكبوت الأحمر لمحاصيل البازلاء
} السكرية والبازلاء

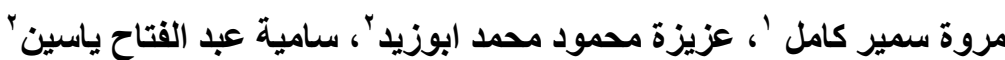

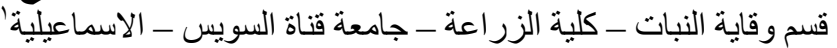

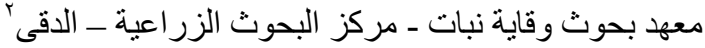

أجريت الدر اسات لتحديد مستوى الإصابة لمحاصيل الباز لاء و الباز لاء الحلوة بأكاروس العنكبوت الأحمر والاكاروس الدفترس خلال

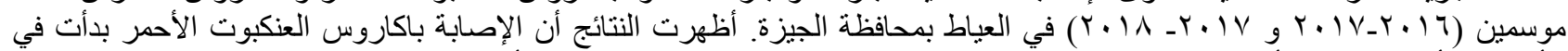

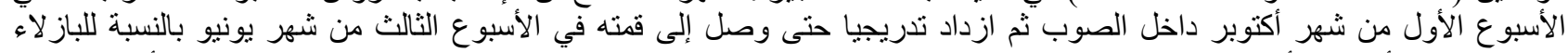

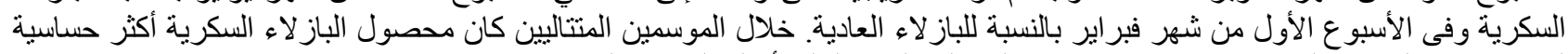

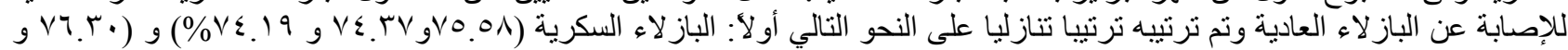
ثر.V

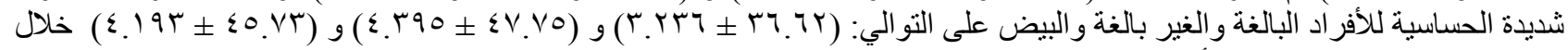

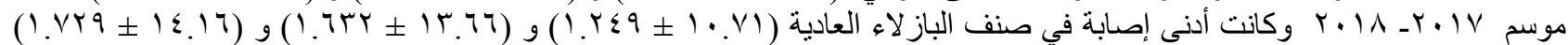

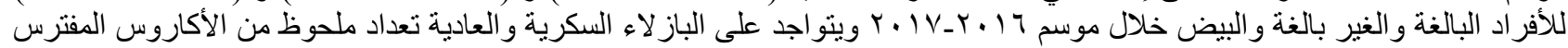
وكان ذالقئ (Amblyseius swirskii (Athias-Henriot)

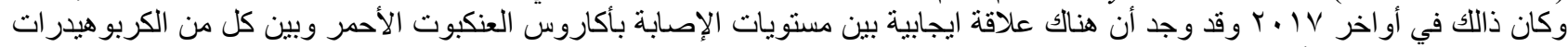

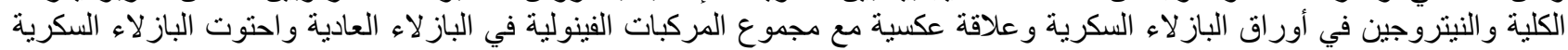

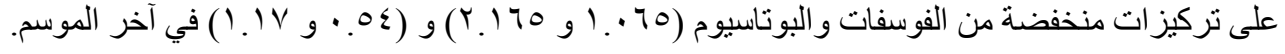

